\title{
Health Law Comes of Age: Economics and Ethics in a Changing Industry
}

Law, Medicine, and Forensic Science (3d ed.). By William J. Curran and E. Donald Shapiro. Boston: Little, Brown and Co., 1982. Pp. xxix, 1132. $\$ 28.00$.

\section{Clifford D. Stromberg $\dagger$}

Health law is booming. This field of legal practice hardly existed twenty years ago; it is now becoming one of the more important legal specialties. Until recently, practice in the "medico-legal" field was largely limited to the defense of hospitals and physicians in malpractice actions and to occasional issues in criminal law. Today, "health law"1 is a diverse and burgeoning enterprise. The National Health Lawyers Association alone boasts more than 2200 members. There are also specialty groups of hospital lawyers, food and drug lawyers, mental health lawyers, and others. Professional journals, books, courses, and symposia on health law are proliferating.

These developments reflect the dynamic growth of the health industry. Health care is now the nation's third largest industry (after construction and agriculture), with national health expenditures that exceeded $\$ 280$ billion in 1981. Health costs have leaped from about 4.0 percent of our gross national product in 1960 , to 5.9 percent in 1970, and to 9.8 percent in 1981. Health care constitutes about one-third of the service sector and is the fastest growing portion of this fastest growing sector of our economy. ${ }^{2}$

The recent surge in health law practice has also been spurred by enactment of a formidable array of laws and regulations concerning Medicare/

$\dagger \quad$ The author is a partner at Dorsey \& Whitney, Washington, D.C. He was formerly Deputy Executive Secretary, U.S. Department of Health and.Human Services, and a consultant on health law and policy to the Federal Trade Commission.

1. The term is significant. The traditional terms "forensic medicine" and "medical jurisprudence" betoken the fact that health issues rose to legal significance almost exclusively in the limited context of proving facts (such as paternity, insanity, cause of death, or malpractice) in court. As the more general term "health law" suggests, there is now a substantial body of law governing the relations of health care providers, professionals, third-party payors, and patients in broader contexts.

2. See Reilly \& Legge, The Embattled Hospital: Cost Control Measures Versus Imperatives for Expansion, 7 J. HEALTH POL., POL'Y \& L. 254, 255 (1982); Federal Trade Comm'n, Health Services Policy Session, 1-5 (June 5, 1979); Cost of Health Care Rose to $\$ 287$ Billion in 1981, Wash. Post, July 27, 1982, at A2, col. 4. 
Medicaid reimbursement, health planning, the Hill-Burton program for hospital construction, Professional Standards Review Organizations, federally qualified Health Maintenance Organizations (HMOs), state hospital rate setting, and so on. State and federal reimbursement rules for health providers alone rival the Internal Revenue Code regulations in complexity.

Finally, the emergence of health law as a distinct field of practice has been aided, I believe, by a perception that many of the most challenging issues concerning law and society arise in this area. Legal questions as to the allocation of scarce medical resources, rights to health care, abortion, genetic engineering, treatment of mental patients, definition of death, and prolongation of life have spurred great public and professional interest in recent years. For all these reasons, health law has emerged as a specialty with both an economic impetus and, if not yet overall intellectual coherence, then at least a core of principled concerns.

In this context, publication of the third edition of Curran and Shapiro's Law, Medicine, and Forensic Science ${ }^{\mathbf{s}}$ is timely and important. This is a superb book, of great significance for both practitioners and students in the health professions and law. Its diverse sources, compendious notes, brisk editing, and pragmatic orientation make it the single most useful volume I know of for the health lawyer.

Curran and Shapiro's work is more than a casebook. While most casebooks contain long excerpts from appellate decisions followed by a few questions of mainly theoretical significance, Curran and Shapiro's excerpts are short and well-edited. They are followed by copious notes on subsequent cases, statutes, legal writings, medical journal reports, and empirical studies. The authors have included a useful array of materials not usually accessible to lawyers beginning work in the health field. These include a description of the hospital industry, a glossary of medical terms, sample medical reports, typical hospital forms, professional codes of ethics, and medical journal writings.

The organization of Law, Medicine, and Forensic Science is also wellconceived, particularly for the practicing professional. The chapters, topics, and notes are arranged almost in treatise form, so that locating authorities on particular subjects is made easy. In all respects, this is an exceptionally fine contribution to the health law field.

3. W. GurRan \& E. Shapiro, LAW, MEDICINE, AND Forensic SCIENCE (3d ed. 1982) [hereinafter cited by page number only]. 
I.

In considering many of the issues with which Law, Medicine, and Forensic Science deals, it is helpful to bear in mind the depth of the conflict between medicine and law. Curran and Shapiro wisely begin by examining the "dialogue between these too often divergent and conflicting fields of human endeavor."" Anyone who works in health law or policy must be struck by the bitter, multi-issue battle between health care providers-especially doctors-and lawyers. George Bernard Shaw said that every profession is a conspiracy against the laity. Lawyers and doctors at times appear to believe that the others' profession is a conspiracy against sweet reason itself.

The legal-medical conflict can be seen at many levels. It begins with the epistemological premises of each profession about what is knowable and how the knowable can be learned. Since the Greeks, philosophy has been cleaved by the distinction between rationalists and empiricists, or more crudely, between a deductive and an inductive approach to deriving conclusions. Physicians, having been trained as scientists, are generally empiricist in orientation and inductive in reasoning. They proceed from clinical observations to hypotheses, to diagnoses, to treatments, and finally to revised or confirmed conclusions based on the results of treatment. Because patients are so biologically diverse, and their needs so often exigent, physicians have little respect for operational rules per se, believing that treatments are validated by the results with particular patients.

Lawyers, on the other hand, are rationalists-at least by aspiration. They respect facts greatly and spend most of their time assembling them. But in their intellectual orientation, lawyers are deductive. They begin with preexisting principles of law and analyze whether the facts of a given situation justify the application of one or more of these principles. Most lawyers believe that facts and people can and ought to be made to adhere to rules, and that exceptions bear a heavy burden of justification.

Lawyers and doctors also begin with different views of human nature and society. Medicine is more deterministic, while law stresses free will and responsibility. Doctors conceive of their profession as altruistic; their world view is based on voluntary devotion to duty rather than obligatory obedience to rules. Lawyers, in contrast, live in a Hobbesian universe. They tend to see society as inherently chaotic, restrained only by the rule of law. Indeed, at times they seem to believe that no significant role in society-including any health profession-can honorably be discharged unless it is strictly constrained by legal rules.

4. P. 1. 
Particularly in courtroom situations, doctors and lawyers find one another vexatious. Lawyers are passionately devoted to the notion that truth will emerge only if each side clearly states its position and vigorously attacks the other. In court, they prey on the popular misconception of science as a set of immutable laws established by objective, indisputable observations. Against this fanciful model it is easy to impeach the qualified and fallible testimony of any mortal physician.

Physicians are disinclined to state bald conclusions and prefer simply to describe their findings. In their view, "[t]he adversary system squeezes the doctor into roles and settings with which he is unfamiliar and in which he is ineffective ...." As a result, the adversary process "is clearly ineffective in establishing truth in medicine." Doctors' views of court procedures recall H.L. Mencken's comment that in a courtroom, Jesus Christ and Judas Iscariot stand as equals-except that the betting odds favor Judas." This tension between the medical-scientific and legal perspectives, between pragmatic solutions and imperative rules, charges many of the central issues in health law which Curran and Shapiro examine.

II.

I will discuss only a small sample of the issues which this book addresses: problems of forensic proof, regulation of the health industry, informed consent to medical treatment, and antitrust law and the health field.

\section{A. Problems of Forensic Proof}

Curran and Shapiro outline clearly the opportunities and difficulties in using science to prove biomedical facts in litigation. One can begin with a corollary to Karl Popper's point that scientific hypotheses cannot be conclusively proven, only disproven, since we can never be sure that no contrary case exists. Thus, in criminal cases "logically, at least, [it is] easier to prove innocence than guilt." Proof of innocence requires only one piece of credible alibi evidence, while proof of guilt beyond a reasonable doubt requires a mass of evidence that excludes successively every plausible inference except guilt.

The scientific community is energetically trying to convince the public that science is not simple and pristine, that its laws are not certain and immutable. A number of scientific fields are becoming increasingly proba-

5. P. 19 (quoting Child, Lawyers, Doctors and Medical Malpractice: A Surgeon Reacts, in MEDlCAL MALPRACTICE 56 (Personal Injury Library No. 3, 1966)).

6. PETER'S QUOTATIONS 288 (L. Peter ed. 1977).

7. P. 92 (quoting Walls, Whither Forensic Science?, 6 MED., SCl., \& L. 183, 187 (1966)). 
bilistic. It has been said that "communication from science to law, which was never easy, is being made more difficult by this developing trend towards scientific results being expressed as probabilities . . . "\$ The law, scientists complain, wants sure answers and not mere probabilities. In fairness, however, the law is rarely so inflexible. In virtually every state, the standard that medical testimony must meet in order to be probative is not certainty but only "a reasonable degree of medical certainty." The standards of "preponderance of the evidence," "clear and convincing proof," and "beyond a reasonable doubt" have been described at times by reference to percentages of certainty, such as fifty-one percent, seventy-five percent, and ninety-five percent, respectively. Increasingly it is recognized that many legal decisions may properly rest on probabilities. ${ }^{10}$

As Curran and Shapiro make clear, in recent years a growing list of scientific techniques has been proffered for use in the courtroom. ${ }^{11}$ The judicial response to these techniques frequently has been skeptical or even hostile. The opposition to their use is based on several recurring arguments: that a particular scientific test is unreliable; that if reliable it is nevertheless susceptible to misinterpretation; that even if properly interpreted, it will be weighed too heavily by the jury; and that even if properly weighed, it is unacceptably intrusive or unethical. As a New York court said in denying admission of a chemical analysis of blood residues on a defendant's clothes:

This Court cannot stress too much its fear of undue prejudice to defendant in the receipt of this questionably accepted scientific testimony. . . . The admission of this testimony, with a seeming scientific imprimatur, pointing to female blood on defendant's jacket . . . would in the Court's view be highly prejudicial to the defendant, far outweighing its probative value. ${ }^{12}$

Some early California cases on the use of blood group testing for determining paternity sought to mitigate this problem by admitting the test only on the same grounds as other expert testimony and leaving the jury

8. Pp. 92-93.

9. See, e.g., State v. Webb, 309 N.W.2d 404, 413-14 (Iowa 1981); Commonwealth v. Webb, 449 Pa. 490, 495, 296 A.2d 734, 737 (1972).

10. Sec, e.g., United States v. Fatico, 458 F. Supp. 388, 410 (E.D.N.Y. 1978); Brilmayer \& Kornhauser, Review: Quantitative Methods and Legal Decisions, 46 U. CHI. L. REV. 116 (1978); Gerjuoy, The Relevance of Probability Theory to Problems of Relevance, 18 JURIMETRICS J. 1 (1977); McCauliff, Burdens of Proof: Degrees of Belief, Quanta of Evidence, or Constitutional Guarantees?, 35 VAND. L. REV. 1293 (1982); Stripinis, Probability Theory and Circumstantial Evidence: Implications from a Mathematical Analysis, 22 JURIMETRICS J. 59 (1981).

11. These include polygraph tests, hypnosis, voice stress analysis, voice prints (spectrograms), narcoanalysis, neutron activation analysis, breathalyzer tests for intoxication, and blood group tests and serology.

12. People v. Alston, 79 Misc. 2d 1077, 1087-88, 362 N.Y.S.2d 356, 365 (Sup. Ct. 1974). 
free to weigh the evidence as it wished. ${ }^{13}$ More recently, courts and government agencies have taken the view that undisputed biological laws should not be disregarded. ${ }^{14}$ In a pivotal decision, Judge Charles Joiner admitted testimony concerning a polygraph examination, saying:

The Court must always be alert to prevent the use of evidence that has marginal utility in the process of truth seeking if it is of such a nature so as to over-impress the jury. . . . [Nevertheless,] the relevancy of the polygraph evidence is high and its use will likely protect both society and the defendant. ${ }^{15}$

Several cases go beyond the core question of whether particular scientific tests are reliable; they ask whether the use of even reliable tests may lead to a "dehumanizing" or "unethical" search for information. As one judge floridly warned, "[the polygraph] would bring closer the spectre of 'Big Brotherism'. . . . [It] threatens to impair human dignity . . . by treating the defendant . . . as an object to be operated upon, [and] tested in a laboratory."18 Curran and Shapiro dryly observe that "[s]cientific challenge to the courts' traditional methods of determining truth seems . . . to bring out judicial hyperbole and vivid imagery." because of the significance of such concerns, most courts still reject polygraph testimony, narcoanalysis (statements made under the influence of truth serum), and hypnosis evidence, absent a stipulation of the parties.

There is no doubt that some forensic techniques loom as especially forbidding because they apparently wrest a defendant's own testimony from him in violation of the spirit of the Fifth Amendment. Other tests, such as voiceprints and forensic dentistry (bitemark evidence), do not pose such sensitive philosophical problems and accordingly have enjoyed wider acceptance. Still other tests, such as neutron activation analysis, are applied only to extrinsic physical evidence and suggest few of the ethical hazards that dominate the debate over forensic use of scientific tests. Moreover, tests such as voiceprints are used primarily in criminal cases, while the polygraph is controversial in part because it is used in a far more troubling array of employment, insurance, and other extrajudicial contexts. As Curran and Shapiro's detailed discussion suggests, scientific tests will play

13. See, e.g., S.D.W. v. Holden, 275 Cal. App. 2d 313, 80 Cal. Rptr. 269 (1969); Berry v. Chaplin, 74 Cal. App. 2d 652, 169 P.2d 442 (1946).

14. See pp. 155-56 (citing court case and administrative rules making blood test results conclusive where paternity is ruled out).

15. United States v. Ridling, 350 F. Supp. 90, $95-96$ (E.D. Mich. 1972). Nevertheless, most courts still exclude polygraph evidence in criminal cases.

16. People v. Barbara, 400 Mich. 352, 421, 424, 255 N.W.2d 171, 201, 202 (1977) (Coleman, J., concurring in part, dissenting in part).

17. P. 166 . 
an increasingly prominent role both in trials and in extrajudicial proceedings. Inevitably, the debate over their legitimate use will intensify in the coming years.

\section{B. Regulation in the Health Industry}

Because of the enormous growth of regulation in the health field, the third edition of Law, Medicine, and Forensic Science contains a new chapter on this subject. Health care, and particularly hospitals, are among the most highly regulated businesses in our economy. ${ }^{18}$ What is less recognized, especially when the debate is reduced to polemical phrases such as "deregulation," is that the health industry is regulated in more diverse ways than most other industries. Health care regulation is ecumenical; it serves ethical, sociological, economic, quality-control, fiscal, and enforcement objectives, at times in contradictory ways.

The most prominent forms of health regulation are limits on the supply of physicians through state medical licensing laws and visa restrictions on foreign medical graduates; limits on the supply of hospitals and expensive equipment through health planning and certificate-of-need laws; regulation of interspecialty competition through medical practice laws, thirdparty payor rules, and hospital staff privileges; regulation of prices through hospital rate setting, reimbursement regulations, and cost-containment rules; regulation of health facility standards through "conditions of participation" for Medicare/Medicaid and rules set by the Joint Commission on Accreditation of Hospitals; regulation of physician conduct through Professional Standards Review Organizations, peer review and mandatory reporting laws; regulation of medical ethics in research and experimental treatment through mandatory Institutional Review Boards; indirect regulation of certain conventional biomedical techniques (such as CAT scans, heart transplants, and "less-than-effective" drugs) through direct reimbursement policies; and direct regulation of special biomedical technologies such as recombinant DNA research, psychosurgery, and in vitro fertilization.

Many of these constraints serve different goals and employ different techniques than classical economic regulation. They do not simply seek to correct market defects such as the existence of economic externalities or gaps in consumer information. They do not fit neatly into either the "public interest" or the "regulatory capture" models of regulation. ${ }^{10}$ Yet they serve widely felt needs, some of which are unique to the health care field.

18. See Federal Trade Comm'n, supra note 2, at 82 .

19. See Reynolds, Prospects for Regulation of the Health Care Sector in the 1980s, in AMERICAN Medical ASs'N, PROFIle OF MEdiCal PRACTICE 1981, at 37 (D. Goldfarb ed.). 
The problems of whether and how to regulate the costs and quality of health care are among the most challenging in our economic life.

Perhaps as a result, the regulation of health care in America has been subject to contradictory and shifting regulatory philosophies. The Department of Health and Human Services (formerly HEW), for example, first tried to increase the aggregate supply of physicians through "capitation" grants to medical schools, to increase the number of hospitals through the Hill-Burton program, and to improve the quality of care by strict conditions of participation and generous reimbursement rules under Medicare and Medicaid. Access to health services and quality of care were the overriding concerns. As health costs skyrocketed and economic theories changed, however, the goal of cost containment became paramount. The capitation grants were phased out; health planning laws were enacted to limit hospital construction; and tighter reimbursement rules were fashioned.

Meanwhile, the Federal Trade Commission (FTC) operated on a very different economic theory of the health industry, and it underwent its own ideological metamorphosis. The FTC moved from zealous regulation to "occupational deregulation" of health professions. The Commission basically accepted the theory that physicians "induce" demand for their services in order to achieve "target incomes." While HEW viewed professional practice rules as promoting quality of care, the FTC saw them as unjustified restraints of trade that protected poor quality care by some professionals. While HEW saw continuity of care and preventive health services as key considerations, the FTC sought through "occupational deregulation" to fractionate care into its most efficient economic units (for example, having dental care provided by independent and competing hygienists, extended function dental assistants, dentists, endodontists, and orthodontists). While HEW believed physicians' participation was crucial to cost-containment efforts, the FTC sought to reduce drastically physician participation on Blue Shield plan governing bodies.

Although HEW and the FTC have sometimes worked harmoniously (for example, in developing the Model Drug Product Selection Act and in encouraging HMO development), their divergent perspectives are symptomatic of the basic problem of health care regulation: Almost everyone agrees that the economics of health care are unusual, but few can agree on what to do about it. The neoclassical model of a competitive market assumes that there are many sellers who act relatively independently and without regulation, that consumers are well informed about prices and are able to judge quality, that competition drives prices down to average cost levels, and that if prices fall below marginal (or average) costs, factors of production move to other lines of business. This model is, however, 
largely inapplicable to our current health care system. A great deal of basic empirical research is still being brought to bear on the most fundamental economic issues in health care. ${ }^{20}$ In this unsettled theoretical environment, it is not surprising that conflicting regulatory policies persist.

Curran and Shapiro's chapter on regulation introduces many of the significant trends in health care regulation: state licensing of a growing number of health professions; tougher self-policing of competence and ethics by the professions themselves; greater constraints on physician conduct; growing judicial review of hospital staff privileges and other hospital management decisions; increasing use of formalized peer review and risk management programs; frequent litigation over certificates of need and licensure; and persistent demands that hospitals act like charities (for example, by providing emergency care to all who need it) while they are regulated like businesses. Curran and Shapiro capture the ongoing tensions in health care regulation. These include the complex interplay among rules, quality of care, and health costs, and the need to apply the rigors of the competitive market to an industry which still operates with a strong altruistic ethos.

\section{Informed Consent to Treatment}

Curran and Shapiro explore not only the usual contexts in which important legal doctrines may be applied, but the less obvious ones as well. For example, while most authors discuss the doctrine of informed consent to health care only in the context of consent to surgery or psychiatric care, Curran and Shapiro also discuss it with reference to immunization and vaccination programs, the Food and Drug Administration's proposal for "patient package inserts" to prescription drugs, and medical experimentation. Informed consent is shown to be a slippery concept whose shape changes with the context. The section on informed consent begins with Justice Blackmun's rudimentary definition of such consent as "the giving of information to the patient as to just what would be done and as to its consequences." 21 This is followed by the question, "Do you find Justice Blackmun's definition adequate?"32 The point, of course, is that such a formulation of informed consent does not provide any role for the patient and does not capture the varying meanings of informed consent in various contexts.

20. See Sloan, Competition Among Physicians, in FEDERAL TRADE COMM'N, COMPETITION IN THE HeAlTH CARE SECTOR: PAST, PRESENT, AND FUTURE 57 (W. Greenberg ed. 1978). But see Gaffney, Cotterill \& Meeker, Competitive Forces in the Market for Physicians' Services: A Survey of Current Research, in AMERICAN MEDICAL ASs'N, supra note 19, at 3.

21. Planned Parenthood v. Danforth, 428 U.S. 52, 67 n.8 (1976).

22. P. 411. 
In recent years, the debate over informed consent has swung from the practical toward the philosophical. This change may have been a useful corrective to the many years during which the doctrine of informed consent was an article of faith without articulated content. But that situation changed dramatically during the 1970 's, as a series of thoughtful writers focused on honesty and lying in medical relations, on the ethical obligations of physicians, and on the meanings of "voluntary" and "substituted" consent when patients are impaired. ${ }^{23}$ Our understanding of informed consent therefore has become more sophisticated.

It has become clear that the questions which must now be answered are intensely practical and empirical. What risks are sufficiently predictable to be properly revealed? What are the psychological and physiological costs of revealing remote risks to fragile patients? How do patients' minds receive, "encode," and retrieve information concerning treatment? How much do patients really understand? As to these questions, there is relatively little empirical information. ${ }^{24}$ Yet, even the existing body of research makes clear that the doctrine of informed consent-however formulated-frequently does not work the way it should. Several studies have indicated that a great many patients are told and understand only a small fraction of the information relevant to their medical decisions. ${ }^{25}$

This disconcerting reality focuses our attention on the fact that legal informed consent entails two separate questions: Has the physician discharged his duty to disclose adequate information, and has the patient comprehended enough and engaged in a voluntary decision-making process such that his consent can be accepted?

For many years, the law required physicians to disclose to patients only information that most physicians in the community would have disclosed. ${ }^{26}$ But beginning in 1972 with Canterbury v. Spence, ${ }^{27}$ some courts

23. See, e.g., S. BOK, LYING (1979); Meisel, Roth \& Lidz, Toward a Model of the Legal Doctrine of Informed Consent, 134 AM. J. PSYCHIATRY 285 (1977); Romano, Reflections on Informed Consent, 30 ARChives Gen. PSYChIATRY 129 (1974); NATIONAL COMM'N FOR PROTECTION OF HUMAN SUBJECTS OF BIOMEDICAL AND BEHAVIORAL RESEARCH, THE BELMONT REPORT: ETHICAL PRINCIPLES AND GUIDELINES FOR THE PROTECTION OF HUMAN SUBJECTS OF RESEARCH (1979).

24. For some of the existing research, see Cassileth, Zupkis, Sutton-Smith \& March, Informed Consent-Why Are Its Goals Imperfectly Realized?, 302 NEW ENG. J. MED. 896 (1980); Grundner, On the Readability of Surgical Consent Forms, 302 NEW ENG. J. MED. 900 (1980); Hagman, The Medical Patient's Right to Know: Report on a Medical-Legal-Ethical Empirical Study, 17 U.C.L.A. L. REV. 758 (1970); Woodward, Informed Consent of Volunteers: A Direct Measurement of Comprehension and Retention of Information, 27 CLINICAL RESEARCH 248 (1979).

25. See, e.g., Meisel \& Roth, What We Do and Do Not Know About Informed Consent, $246 \mathrm{~J}$. A.M.A. 2473 (1981); NATIONAL COMM'N FOR PROTECTION OF HUMAN SUBJECTS OF BIOMEDICAL AND BEHAVIORAL RESEARCH, RESEARCH INVOLVING THOSE INSTITUTIONALIZED AS MENTALLY INFIRM (1978); see also Stromberg \& Stone, A Model State Law on Civil Commitment of the Mentally III, 20 HARV. J. LEGIS. (1983) (forthcoming) (summarizing studies on informed consent to psychiatric and other medical care).

26. See, e.g., Natanson v. Kline, 187 Kan. 186, 190, 354 P.2d 670, 673 (1960).

27. 464 F.2d 772 (D.C. Cir. 1972). For a summary of developments after Canterbury, see Sard v. 


\section{Health Law}

rejected the notion that the medical profession could set its own standard of disclosure and held instead that a physician has a "duty to impart information which the patient has every right to expect." tient's right of self-decision shapes the boundaries of the duty to reveal."29 Risks must be disclosed if a reasonable person in the position of the patient "would be likely to attach significance to the risk or cluster of risks in deciding whether or not to forego the proposed therapy." was still focused on what the physician disclosed, not on what the patient understood or decided.

The problem remains of devising a viable model of informed consent that does focus on the patient's mental processes but that is also workable in the context of urgent hospital decisions. Hospital staff cannot all be turned into psychiatrists, priests, or oracles forced to guess what has penetrated the deep recesses of a patient's understanding or what myriad factors have influenced his decision. They are, after all, under legal and ethical obligations to act-often quickly-based on what is medically necessary for the patient, unless the patient competently declines.

Curran and Shapiro underscore how broad and sometimes problematic the doctrine of informed consent can be by juxtaposing Canterbury v. Spence with Truman v. Thomas. ${ }^{91}$ In the latter case, the California Supreme Court reversed a jury verdict for the defendant physician on the ground that the physician had a duty not only to advise his patient to have a pap smear test, but also to lecture her repeatedly on the risks if she persisted in refusing to undergo the test. As the dissent pointed out:

Carried to its logical end, the majority decision requires physicians to explain to patients who have not had a recent general examination the intricacies of chest examinations, blood analyses, X-ray examinations, electrocardiograms, urine analyses and innumerable other procedures . . . . Requiring physicians to spend a large portion of their time teaching medical science before practicing it will greatly increase the cost of medical diagnosis - a cost ultimately paid by an unwanting public. Persons desiring treatment for specific complaints will be deterred from seeking medical advice once they realize they will be charged not only for treatment but also for lengthy lectures on the merits of their examination. ${ }^{32}$

Hardy, 34 Md. App. 217, 367 A.2d 525 (1977). Most states adhere to the pre-Canterbury rule.

28. 464 F.2d at 782 .

29. Id. at 786 .

30. Id. at 787 (quoting Waltz \& Scheuneman, Informed Consent To Therapy, 64 NW. U.L. REV. $628,640(1970))$.

31. 27 Cal. 3d 285, 611 P.2d 902, 165 Cal. Rptr. 308 (1980).

32. Id. at 298-99, 611 P.2d at 910, 165 Cal. Rptr. at 316 (Clark, J., dissenting). 
Although this is an extreme case, the doctrine of informed consent does remain an unsatisfactory compromise between ethical aspirations and the realistic limits of human communication and economic life. Curran and Shapiro reveal the ambiguities and problems of this doctrine.

\section{Antitrust Law and the Health Industry}

Although Curran and Shapiro's section on antitrust in the health field is not very long or detailed, it is of great interest because of the rapid pace of legal developments in this area. It has been estimated that more than five times as many antitrust suits have challenged conduct in the health field since 1975 as in the previous eighty-five years. ${ }^{33}$ This flood of litigation has been spurred not only by dynamic expansion in the health industry and aggressive competition among health providers, payors, and professionals, but also by changes in the prevailing legal doctrines. Recently, the Supreme Court and lower courts have systematically expanded the bases for antitrust suits in the health field and have cut back on the available defenses. They have held that virtually any hospital affects interstate commerce sufficiently to satisfy the jurisdictional requirements of the antitrust laws, ${ }^{34}$ truncated the "learned professions" exemption, ${ }^{36}$ narrowed the McCarran-Ferguson Act exemption for the "business of insurance" as applied to health care reimbursement plans, ${ }^{36}$ ruled that health planning laws do not confer absolute antitrust immunity, ${ }^{37}$ and narrowly construed the Parker v. Brown ${ }^{38}$ defense based on state authorization. ${ }^{39}$

Consequently, there has been increasingly brisk antitrust activity in several health areas, including challenges to hospital staff privileges, ${ }^{10}$ physician efforts to discourage development of $\mathrm{HMOs},{ }^{41}$ other alleged restraints

33. Halper, The Health Care Industry and the Antitrust Laws: Collision Course, 49 ANTITRUST L.J. 17 (1980).

34. See Hospital Bldg. Co. v. Trustees of Rex Hospital, 425 U.S. 738 (1976).

35. See, e.g., Arizona v. Maricopa County Medical Soc'y, 102 S. Ct. 2466 (1982); National Soc'y of Professional Eng'rs v. United States, 435 U.S. 679 (1978); Goldfarb v. Virginia State Bar, 421 U.S. 773 (1975).

36. See, e.g., Union Labor Life Ins. Co. v. Pireno, 102 S. Ct. 1422 (1982) (mem.); Group Health Ass'n v. Royal Drug Co., 440 U.S. 205 (1979); Virginia Academy of Clinical Psychologists v. Blue Shield, 624 F.2d 476 (4th Cir. 1980), cert. denied, 450 U.S. 916 (1981).

37. See National Gerimedical Hospital \& Gerontology Center v. Blue Cross, 452 U.S. 378 (1981).

38. 317 U.S. 341 (1943).

39. See, e.g., Cantor v. Detroit Edison Co., 428 U.S. 579 (1970); City of Fairfax v. Fairfax Hosp. Ass'n, 562 F.2d 280 (4th Cir. 1977), vacated mem., 435 U.S. 992 (1978).

40. See, e.g., Hyde v. Jefferson Parish Hosp. Dist. No. 2, 686 F.2d 286 (5th Cir. 1982), cert. granted, 51 U.S.L.W. 3649 (U.S. Mar. 7, 1983); Robinson v. Magovern, 521 F. Supp. 842 (W.D. Pa. 1981), aff'd mem., 688 F.2d 824 (3d Cir.), cert. denied, 103 S. Ct. 302 (1982).

41. See, e.g., United States v. Halifax Hosp. Medical Center \& Volusia County Medical Soc'y, 5 TRADE Reg. REP. (CCH) I 50,748 (M.D. Fla. 1980); Ohio ex rel. Brown v. Mahoning County Medical Soc'y, 1980-1 Trade Cas. (CCH) I 63,100 (N.D. Ohio 1979); Forbes Health System Medical Staff, [1976-1979 Transfer Binder] TRADE REG. REP. (CCH) I 21,587 (F.T.C. June 27, 1979); 
of trade by professional associations, ${ }^{42}$ insurer-provider prepayment agreements, ${ }^{43}$ hospital mergers, ${ }^{44}$ and the use of "relative value guides."45 Several other areas can be expected to become fertile fields of antitrust activity, including multi-institutional. purchasing and shared service arrangements, professional accreditation activities, physician prepayment plans, and the actions of private "coalitions for health care."

A recurring problem in health antitrust cases is whether a professional group's competitive actions can be separated from its quality control or cost-containment efforts. Curran and Shapiro examine this issue through the leading case of Arizona v. Maricopa County Medical Society. ${ }^{66}$ In that case two foundations for medical care (FMCs) and two county medical societies agreed to set by majority vote the maximum fees that member physicians could claim as full reimbursement for services to policyholders of participating insurance plans. The district court and the Court of Appeals for the Ninth Circuit refused to conclude that such conduct was a per se violation. On the basis of Goldfarb v. Virginia State Bar ${ }^{47}$ and National Society of Professional Engineers v. United States, ${ }^{48}$ the Ninth Circuit concluded that "marketing restraints that regulate professional competition may pass muster under the Rule of Reason even though similar restraints on ordinary business competition would not." ${ }^{\text {"49 }}$ It was conceded that the FMCs' maximum fees were below the state's own maximum reimbursement level for workmen's compensation and other programs. There was only weak evidence that fees were raised, were uniform, or were coercively enforced. And, as the district court found, an anticompetitive purpose had not been proven. Indeed, the Ninth Circuit professed bewilderment because "in truth, we know very little about the impact of this and many other agreements within the health care industry," and "we are uncertain about the competitive order that should exist

Medical Serv. Corp., [1976-1979 Transfer Binder] TRADE REG. REP. (CCH) ๆ 21,195 (F.T.C. Sept. 15, 1976).

42. See, e.g., Boddicker v. Arizona State Dental Ass'n, 549 F.2d 626 (9th Cir.), cert. denied, 434 U.S. 825 (1977); Kreuzer v. American Academy of Periodontology, 516 F. Supp. 1034 (D.D.C. 1981); Bunzel v. American Academy of Orthopaedic Surgeons, 107 Gal. App. 3d 165, 165 Cal. Rptr. 433 (1980).

43. See, e.g., Blue Shield v. McCready, 102 S. Ct. 2540 (1982); Portland Retail Druggists Ass'n v. Kaiser Found. Health Plan, 662 F.2d 641 (9th Cir. 1981); Medical Arts Pharmacy v. Blue Cross \& Blue Shield, 518 F. Supp. 1100 (D. Conn. 1981), affd per curiam, 675 F.2d 502 (2d Cir. 1982); Blue Cross \& Blue Shield v. Michigan Ass'n of Psychotherapy Clinics, 1980-2 Trade Cas. (CGH) I 63,351 (E.D. Mich. 1980).

44. See, e.g., American Medicorp. v. Humana, Inc., 445 F. Supp. 573 (E.D. Pa. 1978); FTC v. American Medical Int'l, 3 TRADE REG. REP. (CCH) Iี 21,851 (F.T.C. July 30, 1981).

45. See, e.g., United States v. American Soc'y of Anesthesiologists, 473 F. Supp. 147 (S.D.N.Y. 1979); United States v. Illinois Podiatry Soc'y, 1977-2 Trade Cas. (CCH) I 61,767 (N.D. Ill. 1977).

46. 102 S. Ct. 2466 (1982), rev'g 643 F.2d 553 (9th Cir. 1980).

47. 421 U.S. 773 (1975).

48. 435 U.S. 679 (1978).

49. 643 F.2d at 560 . 
within the health care industry."

The Supreme Court later reversed the Ninth Circuit in a 4-3 decision. It affixed the term "price fixing" to the challenged activity and concluded that it was illegal per se, despite arguments that "the per se rule did not govern this case because the agreements at issue . . . fix maximum prices, are among members of a profession, are in an industry with which the judiciary has little antitrust experience, and are alleged to have procompetitive justifications."

In the context of traditional antitrust doctrine, the result in Maricopa County is not surprising. But the opinion left a confusing and disturbing residue for the health industry. Although the FMCs performed important peer review and administrative tasks, and although the Court conceded that the impact of the fee maxima on medical fees in general was "a matter of dispute," ${ }^{\prime 2}$ it nevertheless boldly declared that the "price fixing agreements in this case . . . are not premised on public service or ethical norms." Court concluded that the plans would "provide the same economic rewards to all practitioners." schedule is . . . desirable, it is not necessary that doctors do the price fixing." "ss It apparently preferred that insurers limit prices, although the Court did not offer any persuasive reason for this preference. Finally, although the court of appeals had stated flatly that "this record reveals nothing about actual competitive effects of the challenged arrangement," the Supreme Court, in a series of observations couched in phrases such as "it is entirely possible," and "there is no reason to believe," speculated on what the competitive impacts might be. One is left with the uneasy sense that the Court has made broader than necessary law from questionable policy judgments. In doing so, it may have prematurely foreclosed a range of procompetitive, cost-containment measures that the health industry and consumers sorely need. This decision highlights the fact that the science of applying antitrust principles to the unique economics of health care is in only a rudimentary stage of development.

Centripetal forces now at work in the health industry are likely to exacerbate the conflicts between antitrust principles and concerns over quality and cost. The demand for health care increases while resources are ever more limited. Providers continue to compete largely on the basis of quality

50. Id. at 556 .

51. 102 S. Ct. at 2472.

52. Id.

53. Id. at 2475 .

54. Id.

55. Id. at 2477.

56. 643 F.2d at 556. 
rather than price, while the need for cost containment becomes more acute. The growth of hospital management companies and multi-institutional arrangements, service specialization, exclusive service contracts, tight capital markets for new facilities, and intensified competition for reimbursement among provider and physician groups, are additional factors that may lead to an increase in antitrust litigation.

As Curran and Shapiro recognize, antitrust suits are a revealing aspect of the transformation of health care from a genteel discipline governed by its own code of conduct into an industry capable of surviving in a stringent economy. ${ }^{87}$ Whether this transformation is good or bad remains to be seen. If antitrust law is sensibly applied, it might help the health industry to become a more efficient enterprise, better able to serve patients' needs.

III.

Like all compendious works, the third edition of Curran and Shapiro's Law, Medicine, and Forensic Science has some flaws. For example, the section on medical malpractice is excessively long, as compared with more cursory sections on reimbursement issues and health planning. The potentially novel section on international health is devoted to pedestrian World Health Organization documents and treaties. It might better have discussed, for example, the growing international trade in biomedical services. The book does not give the reader much insight into several key developments in the health industry, such as the growth of hospital chains, the ways in which reimbursement rules favor high-technology health services, the economic rationale for hospital cost-containment or certificate of need restraints, or the problems of adverse-selection and cost-shifting in health insurance. It also does not deal with the critical field of environmental and occupational health, although Three Mile Island, cotton dust, and Love Canal are of great public interest and legal significance.

For a book which does so much so well, however, these are very mild criticisms. Curran and Shapiro have chosen as their subject a field that is economically intricate, ethically subtle, and legally complex. They expose its complexities and suggest its theoretical depths, while at the same time providing a useful tool for practicing professionals.

57. Pp. 692-94. 



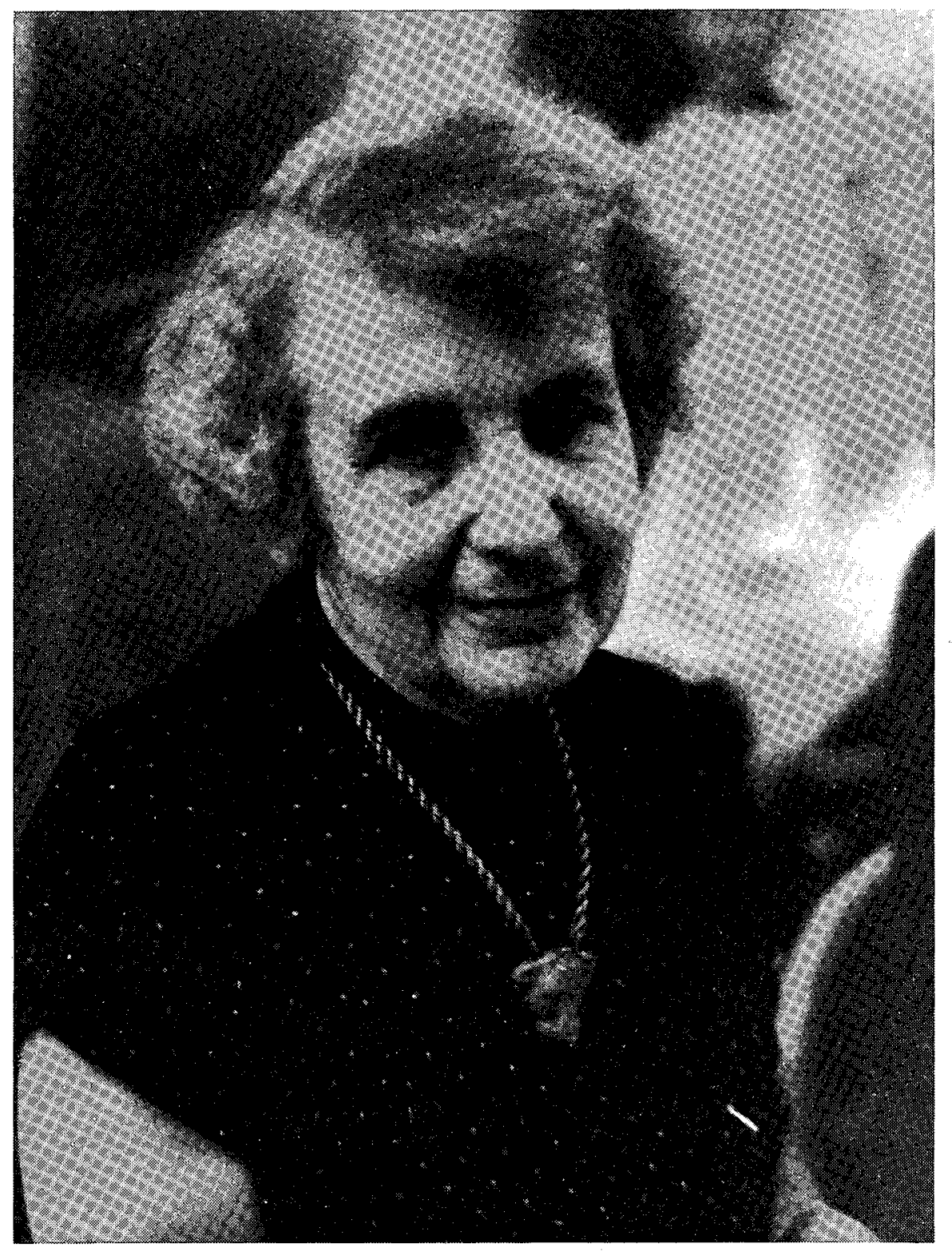

ANNA FREUD (1895-1982) 
